



\section{IAG ring test visual detection of ergot sclerotia in rye 2015}

L.W.D. van Raamsdonk, N. van de Rhee, J.J.M. Vliege, V.G.Z. Pinckaers 
Raamsdonk, L.W.D. van, N. van de Rhee, J.J.M. Vliege, V.G.Z. Pinckaers, 2016. IAG ring test visual detection of ergot sclerotia in rye 2015. Wageningen, RIKILT Wageningen University \& Research, RIKILT report 2016.013. 24 pp.; 2 fig. ; 3 tab. ; 24 ref.

Project number: 126.73 .351 .01

Project title: IAG ringtesten

Project leader: L.W.D. van Raamsdonk

This report can be downloaded for free at http://dx.doi.org/10.18174/393609 or at www.wur.eu/rikilt (under RIKILT publications).

(c) 2016 RIKILT Wageningen University \& Research

The client is allowed to publish or distribute the full report to third parties. Without prior written permission from RIKILT it is not allowed to:

a) publish parts of this report;

b) use this report or title of this report in conducting legal procedures, for advertising, acquisition or other commercial purposes;

c) use the name of RIKILT other than as author of this report.

P.O. Box 230, 6700 AA Wageningen, The Netherlands, T +31 (0)317 4802 56, E info.RIKILT@wur.nl, www.wur.eu/rikilt. RIKILT is part of Wageningen University \& Research.

This report from RIKILT has been produced with the utmost care. However, RIKILT does not accept liability for any claims based on the contents of this report.

RIKILT report 2016.013

Distribution list:

- International Association for Feeding stuff Analysis (IAG), Section Feeding stuff Microscopy (I. Paradies-Severin, J. Vancutsem, G. Frick, R. Weiss)

- European Commission (EC; F. Verstraete)

- Joint Research Centre, Geel (IRMM-JRC; C. von Holst, A. Boix-Sanfeliu)

- All participants of the ring test

- Netherlands Food and Consumer Product Safety Authority (NVWA; W. Ooms, R. Theelen, R. Herbes) 


\section{Contents}

$\begin{array}{ll}\text { Summary } & 5\end{array}$

$\begin{array}{lll}1 & \text { Introduction } & 7\end{array}$

$\begin{array}{llr}2 & \text { Methods } & 8\end{array}$

$\begin{array}{lll}2.1 & \text { Materials } & 8\end{array}$

$\begin{array}{lll}2.2 & \text { Procedure for production } & 8\end{array}$

$\begin{array}{lll}2.3 & \text { Homogeneity study } & 8\end{array}$

2.4 Organization of the ring trial $\quad 8$

$\begin{array}{lll}2.5 & \text { Analysis of results } & 9\end{array}$

$\begin{array}{lrr}3 & \text { Results } & 10\end{array}$

3.1 Application of the method 10

3.2 Recovery 10

4

$\begin{array}{ll}\text { Discussion } & 12\end{array}$

$4.1 \quad$ Criteria for recovery $\quad 12$

4.2 Validation of visual detection of ergot sclerotia 12

$\begin{array}{lll}4.3 & \text { Relevance } & 13\end{array}$

$5 \quad$ Conclusions and recommendations $\quad 14$

$\begin{array}{ll}\text { Acknowledgements } & 15\end{array}$

$\begin{array}{ll}\text { References } & 16\end{array}$

$\begin{array}{lll}\text { Annex } 1 & \text { List of participants } & 18\end{array}$

$\begin{array}{llr}\text { Annex } 2 & \text { Instructions } & 19\end{array}$

Annex $3 \quad$ Results sample A (spike level 400 ppm) 20

$\begin{array}{lll}\text { Annex } 4 & \text { Results sample B (spike level } 1000 \text { ppm) } & 21\end{array}$

$\begin{array}{lll}\text { Annex } 5 & \text { Overview of participants' comments } & 22\end{array}$ 



\section{Summary}

Ergot alkaloids are recognised as seriously toxic compounds, which caused a series of outbreaks in the past. In the EU, enforcement is implemented by visual detection and quantification of ergot sclerotia produced by moulds of the genus Claviceps.

On behalf of the IAG section Feedstuff Microscopy, RIKILT organised a ring test for the visual detection of ergot sclerotia in two unground rye samples in September 2015. In this report the results from the ring test for ergot in rye 2015 are presented.

The ring test ergot sclerotia in rye was designed to test the capability to visually detect sclerotia or parts thereof at relatively high levels. One sample was based on a level of approx. 400 ppm, and the second sample contained an amount of approx. $1000 \mathrm{ppm}$ (EU legal limit for feeds and ingredients: $1000 \mathrm{ppm}=1 \mathrm{gram} / \mathrm{kg}=0.1 \%)$. An amount of approx. 250 grams of rye grains was chosen as sample size. All samples were individually spiked. Thirty participants enrolled for the ring test. Participants were requested to report the number of recovered (fragments of) sclerotia and the total weight per sample. The percentage of recovery for every sample was calculated. A dedicated IAG method as well as other (lab internal) methods were allowed for application. Principally, methods are based on sieving (preferably with a mesh size of $0.5 \mathrm{~mm}$ ), examination of every particle (grain) in the fraction with full grains or particles larger than $0.5 \mathrm{~mm}$, selection of sclerotia fragments supported by documentation, and weighing the final selection of bodies.

The average recovery for both samples was approx. 97\%. All results except one were between the expected recovery limits $(80-110 \% \mathrm{w} / \mathrm{w})$. Supporting data from an intralaboratory validation study of the IAG method showed trueness at different low spike levels between 98 and 105\% w/w. Limit of detection was established at 7 ppm.

It can be concluded that examination by visual detection of sclerotia is a valuable indicator of the expected presence of ergot alkaloids. The results of this study provides the data for a partial validation of the method of IAG for the examination of whole kernel cereal samples. 


\section{Introduction}

Some of the first documented cases of food poisoning caused by infested plant ingredients are the intoxications by ergot alkaloids in north Norway early 17th Century (Alm, 2003) and in New England in the late 17th Century (Woolf, 2000), among other cases (Scott, 2009). The intoxication symptoms were already known as Saint Anthony's fire from the Middle Ages (Lee, 2009a). After an outbreak in France (Pont St. Esprit; Lorenz and Hoseney, 1979; Scott, 2009) in 1951 increased attention was given to the analysis of ergot alkaloids.

Sclerotia or ergot bodies are the fruit bearing mycelia of the moulds of the genus Claviceps. They start growing before the fruit of cereals is starting to form, and in this way the grain is replaced. The ergot alkaloids are principally produced in the sclerotia, but ergot alkaloids were occasionally detected in visually non-detectable infestations of cereal samples, and sclerotia were found without any detectable level of ergot alkaloids (Mulder et al., 2012). Ergot content in individual sclerotia can vary considerably (Lorenz and Hoseney, 1979; EFSA, 2005; Krska and Crews, 2008; Scott, 2009).

Although the alkaloids are the primary cause of disease symptoms, the detection of sclerotia is currently the target of the official control. A limit of $1000 \mathrm{mg} / \mathrm{kg}$ sclerotia is set in the European Union for feed materials and compound feeds containing unground cereals (EC Directive 2002/32/EC (Consolidated version February 2015: European Commission, 2015), whereas an action limit of 500 $\mathrm{mg} / \mathrm{kg}$ sclerotia is set for common wheat and durum wheat in intervention procedures (European Commission, 2009a). The same limit applied to rye in intervention procedures according to Regulation 689/92 (European Commission, 1992), but this regulation was repealed in 2000 (European Commission, 2000). No regulatory limits in the EU apply to ergot bodies in grain for human consumption (Egmond and Jonker, 2004). Other relevant limits are 200-500 mg/kg in cereals depending on purpose (Switzerland), $10 \mathrm{mg} / \mathrm{kg}$ for feed grains and zero tolerance for other grains (UK), and 100-3300 mg/kg depending on cereal species and grade (Canada). Krska and Crews (2008) and Scott (2009) provided detailed overviews of legal limits. Eight out of 21 member states of the European Union reported in 2007 to have detected ergot sclerotia in samples of cereals, making it the most frequently found undesired substance of botanic origin (van Raamsdonk, 2007). The frequency of occurrence ranged from a few samples to a share of $25-50 \%$ positive samples (van Raamsdonk et al., 2009). An increase in occurrence was reported for Germany (Krska and Crews, 2008). Notwithstanding the diverse relationship between amount of sclerotia versus alkaloid content, visual examination prior to chemical analysis, as recommended by EFSA (EFSA, 2005) appeared to be effective (Mulder et al., 2012).

The official method for detection of "besatz" (impurities) in cereals, including sclerotia, according to EC (2009a) is published as official standard (CEN, 2008). In addition, the IAG section Microscopy has developed and published a method for detection of sclerotia in unground cereals or other feeding stuffs (IAG, 2010).

The IAG section Feedstuff Microscopy (http://www.iag-micro.org/) organises annually proficiency tests for a range of topics concerning feed stuff analysis with visual methods. On behalf of this section, RIKILT organised late 2015 a ring test for the visual detection of ergot sclerotia in two unground rye samples. In this report the ring test for ergot in rye 2015 is presented. 


\section{Methods}

\section{$2.1 \quad$ Materials}

The ring test ergot sclerotia in rye was designed to test the capability to visually detect sclerotia or parts thereof at relatively high levels. One sample was based on a level of approx. $40 \%$ of the legal limit, and the second sample contained an amount at approx. 100\% of the legal limit for feed and ingredients $(1000 \mathrm{ppm}=1 \mathrm{gram} / \mathrm{kg}=0.1 \%)$. An amount of approx. 250 grams of rye grains was chosen as sample size.

Rye was obtained from a commercial supplier. The batch was examined for impurities. Specimen of grain weevil (Sitophilus sp.) were removed.

Ergot sclerotia were taken from the RIKILT collection. Large sclerotia were fractionated in order to have comparable numbers of sclerotia fragments in all jars of the same sample.

\subsection{Procedure for production}

Sixty jars (two per participant) were filled with approx. 250 grams of rye grains. Every individually numbered jar was spiked with a number of sclerotia fragments for reaching the necessary weight percentage. Sample size, number and total weight of the sclerotia were stored per jar in order to allow exact evaluation of the results.

\subsection{Homogeneity study}

Control of homogeneity was not necessary, and principally impossible, for the reason that every jar was individually spiked.

\subsection{Organization of the ring trial}

Participants were invited early 2015. A total of 30 IAG members enrolled for the ring test. The participants are listed in Annex 1.

The packages with two jars each were distributed late August 2015 and the result were expected to be submitted early October 2015. All results were received on time. Participants were requested to report the number of recovered (fragments of) sclerotia and the total weight per sample.

Details on the method used were requested to be submitted as well. Instructions are presented in Annex 2.

The general outline of the IAG method for detection of ergot sclerotia (IAG, 2010), in the current case as to be found in unground cereals, consists of the following elements. The entire sample (if necessary in fractions of principally 500 grams) is evaluated in order to avoid problems from inhomogeneity. The method involves weighing the sample, sieving using a sieve of $0.5 \mathrm{~mm}$ and selecting ${ }^{1}$ all sclerotia or fractions thereof. Special attention should be given to grains infested by smut which might mimic sclerotia. Every particle which fits the description of a sclerotium or part of it will be separated. The minimum size of the fragments to be selected is $0.5 \mathrm{~mm}$. Hand books and illustrations will be used to achieve a positive and reliable identification. After a full examination of the sample one or more fractions, ergot sclerotia and other components if selected, remain. The fraction of ergot sclerotia is weighted and the percentage is calculated.

\footnotetext{
${ }^{1}$ It can be helpful to spread a portion of the grains in a large flat bin. The grains preferably form a layer of one grain thick. Every grain is inspected based on shape and colour and moved to a pile of cereal grains in the corner of the bin.
} 


\subsection{Analysis of results}

The percentage of recovery for every sample was calculated. Statistics (average, minimum, maximum) were calculated for sample size, number and weight of sclerotia fragments spiked and number and weight of sclerotia fragments recovered are calculated as well.

Recovery percentage was expected to be between $80 \%$ and $110 \%$. The background of these limits will be discussed further. 


\section{Results}

Thirty packages with two samples were sent to all participants. All participants returned their results. The participants originated from 10 countries. The list of participants is presented in Annex 1 . Half of all participants (15) originated from Germany.

All results were received by E-mail, in most cases by means of a scan and the original report file. Not in all cases a scan as pdf-file was submitted although clearly requested. All reported results were included. One participant did not submit details on the method used.

The full results are presented in the tables of Annex 3 and 4.

\subsection{Application of the method}

Eighteen participants applied the IAG method (IAG, 2010). Four participants reported to have applied method VDLUFA ${ }^{2} 30.2$, one participant referred to another method and six participants indicated to have applied their own internal method.

Eight participants reported the presence of grain weevils in one or both samples. Participants' comments are reproduced in Annex 5.

\subsection{Recovery}

The average recovery was approx. 97\% (Tables 1 and 2). All results except one were between the expected limits (80 - $110 \%)$.

Two participants for sample A and six participants for sample B reported a number of detected sclerotia fragments differing from the spiked number. In three cases this number was higher.

Participant 37 reported three out of four spiked fragments in sample A ( $40 \%$ spike level). Missing one fragment resulted in a recovery of $76.6 \% \mathrm{w} / \mathrm{w}$. Participant 44 reported $300 \mathrm{mg}$ for sample $B$, resulting in a recovery of $109.9 \% \mathrm{w} / \mathrm{w}$.

Table 1 Statistics of the results for the $40 \%$ spike level (400 ppm). Original data in Annex 3.

\begin{tabular}{|c|c|c|c|c|c|}
\hline & \multicolumn{2}{|c|}{ spiked } & \multicolumn{2}{|c|}{ recovered } & recovery percentage \\
\hline average & 4.7 & 114.1 & 4.7 & 110.5 & 96.8 \\
\hline $\min$ & 3 & 99 & 3 & 85.8 & 76.6 \\
\hline
\end{tabular}

Table 2 Statistics of the results for the $100 \%$ spike level (1000 ppm). Original data in Annex 4.

\begin{tabular}{|c|c|c|c|c|c|}
\hline & \multicolumn{2}{|c|}{ spiked } & \multicolumn{2}{|c|}{ recovered } & \multirow[t]{2}{*}{ recovery percentage } \\
\hline & \# sclerotia & mg & \# sclerotia & mg & \\
\hline average & 10.4 & 286.4 & 10.4 & 278.1 & 97.1 \\
\hline $\min$ & 6 & 271 & 7 & 250 & 84.7 \\
\hline
\end{tabular}

\footnotetext{
2 Verband Deutscher Landwirtschaftlicher Untersuchungs- und Forschungsanstalten.
} 
Participants applied either the IAG method or another (VDLUFA or own lab) method. The results obtained with these different methods are not differing. Most results show a recovery between $95 \%$ and $100 \%$, except for four participants at the $40 \% \mathrm{w} / \mathrm{w}$ spike level, and five participants at the $100 \%$ w/w level (Figure 1 and 2).

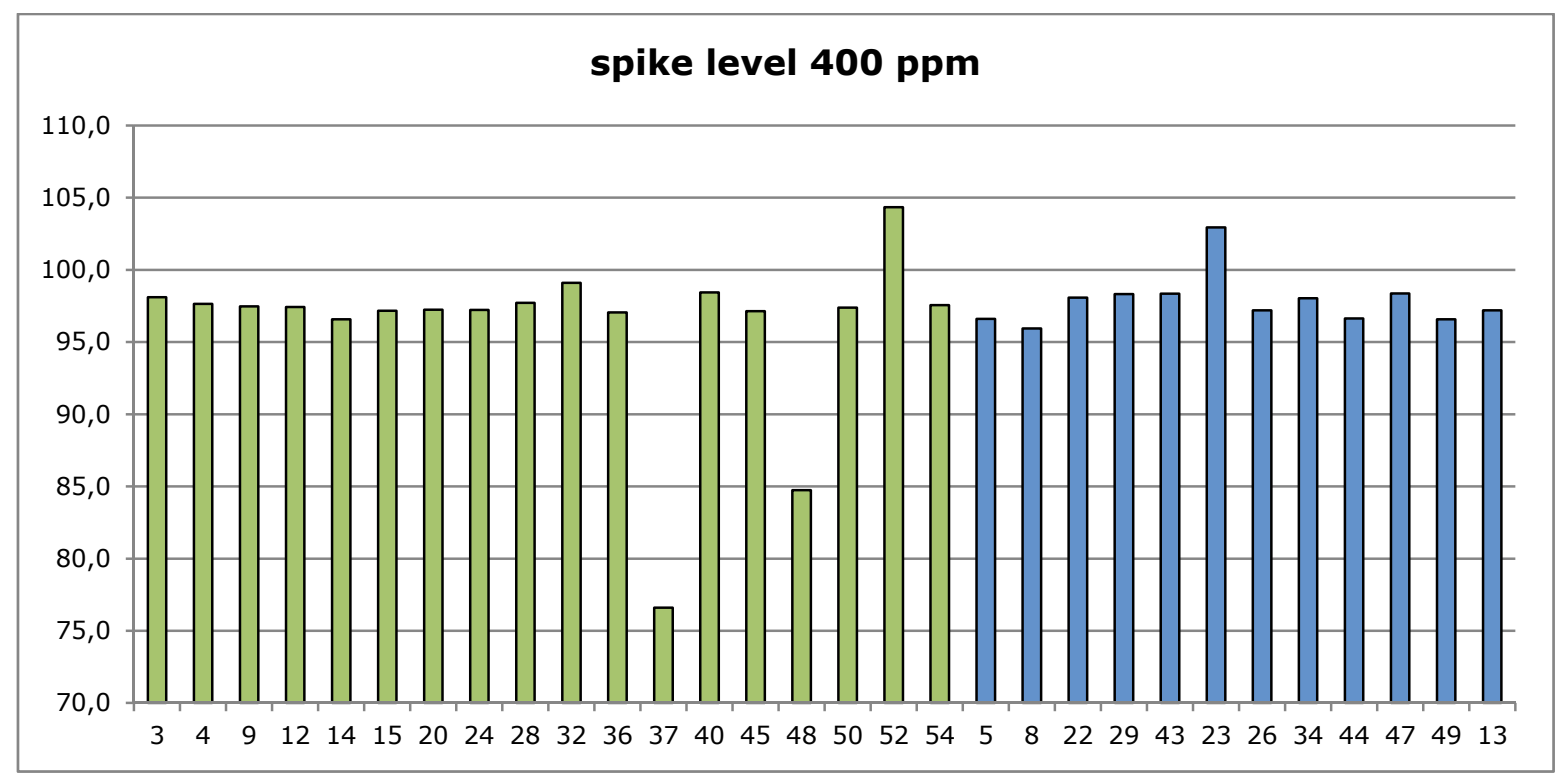

Figure 1 Individual results of the participants at a spike level of $400 \mathrm{ppm}$ (40\% of legal limit). Green: IAG method, blue: other method. Original data in Annex 3. Y-axis: \% recovery.

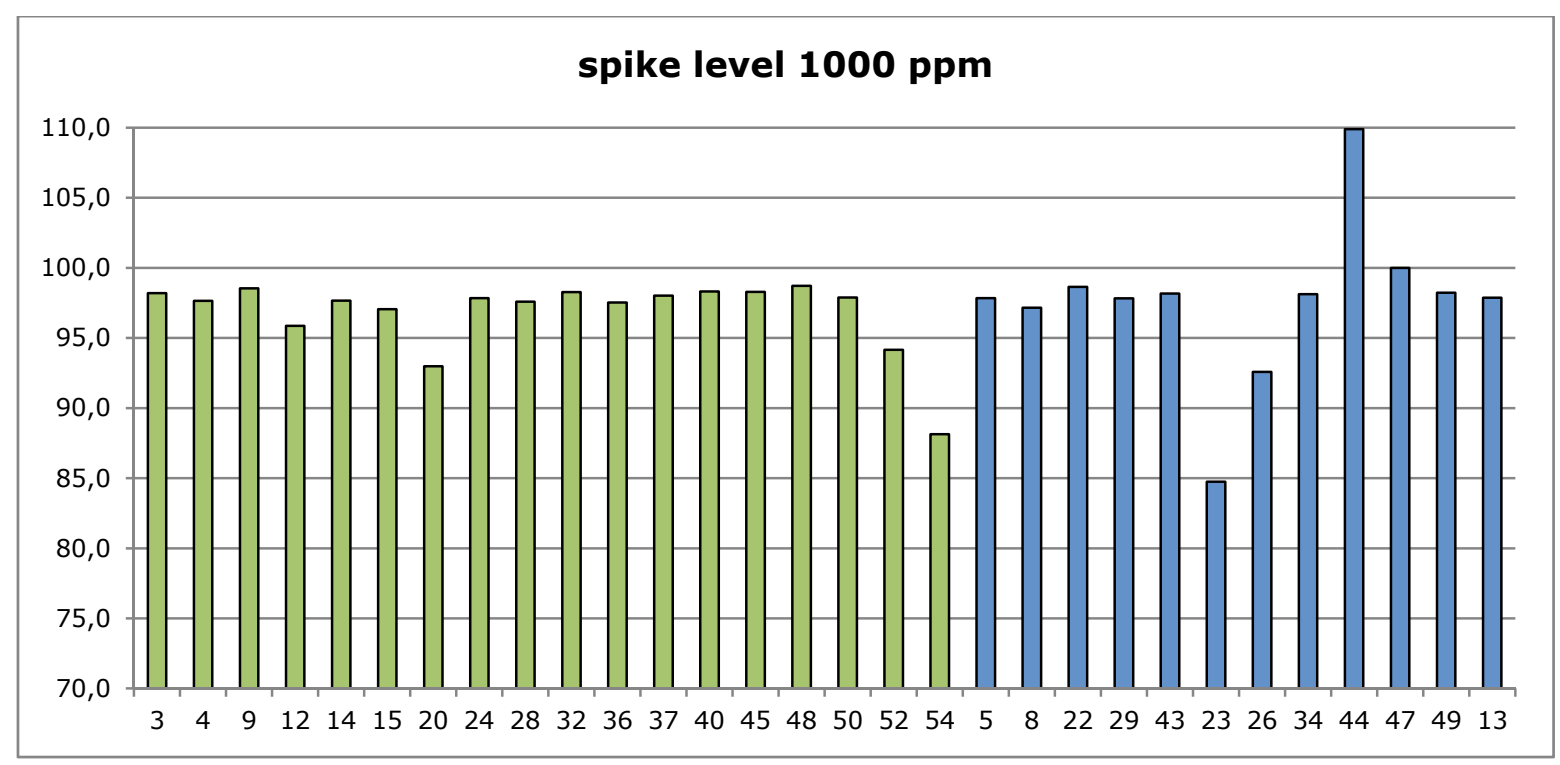

Figure 2 Individual results of the participants at a spike level of 1000 ppm (100\% of legal limit). Green: IAG method, blue: other method. Original data in Annex 4. Y-axis: \% recovery. 


\section{Discussion}

\subsection{Criteria for recovery}

Regulation (EC) 152/2009 presents in Annex II, part C-6 "Measurement uncertainty and recovery rate in case of analysis of undesirable substances", criteria for recovery rate and measurement uncertainty. It is stated that these would not apply to microscopic analysis. It can be argued whether a visual method should be indicated as "microscopic" in strict sense, and in this particular case quantitative results are available. However, as far as encountered, criteria for trueness in general apply specifically to results of chemical methods.

In order to have any indication for criteria for recovery, some indications can be given. Regulation (EC) 152/2009 in Annex II, part C-6, states that a result should be corrected if it exceeds the range between $90 \%$ and $110 \%$ (EC, 2009). Directive 2002/657/EC section 2.3.2.1 indicates limits for recovery of $80-110 \% \mathrm{w} / \mathrm{w}$ for spike levels above $10 \mu \mathrm{g} / \mathrm{kg}$. A note of SANCO $(12571 / 2013)$ presents a general indication of $70-120 \% \mathrm{w} / \mathrm{w}$. RIKILT applies limits of $80-110 \% \mathrm{w} / \mathrm{w}$ for intralaboratory studies, based on CEN information.

Besides few individual deviations, the methods applied in this interlaboratory study generally seems to be fit to detect ergot sclerotia within a recovery rate of $85-105 \% \mathrm{w} / \mathrm{w}$.

\subsection{Validation of visual detection of ergot sclerotia}

Additional information on the performance of the IAG method was collected in an intralaboratory study by RIKILT Wageningen UR, carried out in 2011 (results unpublished). The study comprised a set of six separate experiments to establish different performance parameters. The summarised results are shown in Table 3.

Table 3 Performance parameters of the method for quantification of sclerotia bodies in cereals.

\begin{tabular}{|c|c|c|}
\hline parameter & result & a-priori criterion \\
\hline intra-lab reproducibility $(n=8)$ & $\mathrm{SR}_{\mathrm{w}, 0.2}=9.62 \%$ & $\mathrm{RSD}_{\mathrm{wR}}=20 \%$ \\
\hline accuracy $0.2 \%(n=8)$ & $J=99.5 \%(98.0 \%-100.8 \%), d_{T, \text { rel }}=-0.52$ & $80-110 \% \mathrm{w} / \mathrm{w}$ \\
\hline Limit of detection & $A G_{W}=7 \mathrm{mgr} / \mathrm{kg}(0.0007 \% \mathrm{w} / \mathrm{w})$ & $A G_{W}=0.01 \% \mathrm{w} / \mathrm{w}$ \\
\hline selectivity (niger seeds; $n=2$ ) & $\mathrm{RA}=-0.8 \%$ & $5 \% *$ \\
\hline robustness (time; $n=2$ ) & $R A=-2.3 \%$ & $5 \% *$ \\
\hline
\end{tabular}

The standard deviation of the intra-laboratory reproducibility was $\mathrm{SR}_{\mathrm{w}, 0.2}=9.62 \% \mathrm{w} / \mathrm{w}$. This value complies with the a-priori set criterion. The relative deviation of the accuracy for the eight samples at the contamination level of $0.2 \% \mathrm{w} / \mathrm{W}$ was $d_{T, \text { rel }}=-0.52$, indicating that near to $100 \%$ $\mathrm{w} / \mathrm{w}$ of the contaminated material was recovered. The variation in recovery at the contamination level of $0.01 \%$ is higher. Notwithstanding this result, the recovery is well within the set limits.

The calculation of the limit of detection was based on the analysis of eight samples contaminated at a level of $0.01 \% \mathrm{w} / \mathrm{w}$. The standard deviation of the eight results was $S_{A G}=1.17$, resulting in a detection limit of $A G_{W}=3 * S_{A G}=3.5 \mathrm{mg}$ (calculation according to NEN 7777). As shown, the accuracy at the $0.01 \%$ level is within the set limits, which allows the conclusion that a reliable quantification is sufficiently reached at this level. Since the method was applied to samples of approx. 
500 grams, this detection limit represents a relative amount of $0.0007 \% \mathrm{w} / \mathrm{w}$. The limit of detection is well below the criterion of $0.01 \% \mathrm{w} / \mathrm{w}$ (see Table 3 ).

The relative deviations after adding confusing materials (niger seeds) for determining selectivity and after changing some method parameters (smut infested grains and shorter examination time) for determining robustness are low in all cases (Table 3). Because of the exclusive nature of the presented method parameters, setting criteria is difficult. A deviation of $5 \% \mathrm{w} / \mathrm{w}$ was set as criterion, since this value limits the results including the deviations between the range for recovery of $80-110 \% \mathrm{w} / \mathrm{w}$. The results for selectivity and robustness (smut) are well within this criterion. As alternative, two samples were investigated in duplicate by quick, random examination of the sample as spread in the examination bin for a maximum of 10 minutes or 15 minutes, respectively. The relative deviation (RA) for this alternative examination is within the limit, but higher than for the other parameters (Table 3).

\subsection{Relevance}

The ultimate goal of ergot sclerotia detection is the establishment of the level of the toxic components, the ergot alkaloids, and the effectiveness of a visual examination method should be evaluated in the framework of the performance of the final (e.g. confirmation or identification) analysis. The relationship between visual detection of sclerotia and chemical analysis ergot alkaloids can be compared to the situation for animal proteins. In that case the target of the screening method (microscopy: bone fragments) is not identical to that of the identification method (PCR: DNA) or confirmation method (MS/MS or immunoassay: protein). See for details van Raamsdonk et al. (2007), Liu et al. (2011), Bremer et al. (2012). In both situations the first step in the monitoring procedure is targeting the (possible) vector of the compound at stake. This is principally different from other situations where the target of screening and confirmation is identical (e.g. dioxins screening: CALUX, confirmation: MS; Hoogenboom, 2002; van der Dungen et al., 2016). In those cases the screening method performance can be precisely adjusted to the performance limits of the confirmation method. Therefore, the performance of the currently validated method for visual detection of ergot sclerotia need to be evaluated in the view of chemical results.

Considering the situation that sclerotia show a large range of different levels of alkaloid contents (Lorenz and Hoseney, 1979; EFSA, 2005), a firm statistical relationship between sclerotia weight and ergot alkaloid content cannot be expected. Data for sclerotia weight and ergot alkaloid content in rye, triticale and wheat samples collected in the framework of the Dutch monitoring program (2007-2010) was presented by Mulder et al. (2012). In 82 out of 116 examined samples the visual examination for sclerotia appeared to be a correct, although qualitative, predictor for the presence or absence of ergot alkaloids. In 24 samples, approx. one fifth of all samples, the presence of sclerotia was connected to absence of any ergot alkaloids. The main parameter for comparing the visual and chemical detection was the number of samples which turned out positive for ergot alkaloids in the absence of sclerotia. Less than $9 \%$ (10 samples) was not marked as suspect after visual examination. These samples without sclerotia showed nonetheless ergot alkaloid levels ranging from $5-124 \mu \mathrm{g} / \mathrm{kg}$, with one higher level of $297 \mu \mathrm{g} / \mathrm{kg}$. It is known that cereal grains, showing no infection by moulds of the genus Claviceps, still can contain ergot alkaloids in rare occasions (Mulder et al., 2012).

An alternative to visual examination was studied. The examination based on the detection of sclerotia by means of near-infrared (NIR) was shown to have a limit of detection of $145 \mathrm{mg} / \mathrm{kg}$, and a limit of quantification of $341 \mathrm{mg} / \mathrm{kg}$ (Vermeulen et al., 2012). This is much higher than the LOD of the visual method, but, as stated by Vermeulen et al. (2012) well below the limit as set for feed ingredients in the European Union (EC, 2012: $1000 \mathrm{mg} / \mathrm{kg}$ ). The LOD of the NIR detection method might influence the predictability of the presence of ergot alkaloids. 


\section{Conclusions and recommendations}

It can be concluded that examination by visual detection of sclerotia is a valuable indicator of the presence of ergot alkaloids. The application of visual detection will comply with the requirements as published in EC (2009a). The results of this study provides the data for a partial validation of the method of IAG (2010) for the examination of whole kernel cereal samples. 


\section{Acknowledgements}

The board of IAG section Feeding Stuff Microscopy (dr. I. Paradies-Severin (LUFA, Hameln), dr. G. Frick (ALP, Posieux), ir. J. Vancutsem (FAVV, Tervuren) and dr. R. Weiss (AGES, Vienna)) supported this study as advisory board for communication with the scientists and laboratories working in this research field, and in the final report activities. Their contributions are greatly acknowledged. Thanks to colleagues dr. L. van der Geest, dr. J. de Jong and dr. A. Peijnenburg for the internal RIKILT review procedure. 


\section{References}

Alm, T., 2003. The witch trials of Finnmark, northern Norway, during the 17th century: evidence for ergotism as a contributing factor. Economic Botany 57: 403-416.

Bremer, M., O. Fumière, W. Hekman, A. Marien, A. Kemmers-Vonken, J. A. Fernández Pierna, J. Vliege, V. Baeten, L. van Raamsdonk and G. Berben, 2012. Combination methods for PAP detection and species determination of animal particles. In: Methods for the detection of processed animal proteins, chapter 13, J.S. Jørgenson and V. Baeten, eds.

CEN, 2008. EN 15587 - Cereals and cereal products - Determination of Besatz in wheat (Triticum aestivum L.), durum wheat (Triticum durum Desf.), rye (Secale cereale L.) and feed barley (Hordeum vulgare L.).

Dungen, M.W. van den, Kok, D.E., Polder, A., Hoogenboom, L.A.P., Leeuwen, S.P.J. van, Steegenga, W.T., Kampman, E., Murk, A.J., 2016. Accumulation of persistent organic pollutants in consumers of eel from polluted rivers compared to marketable eel. Environmental Pollution, 219: 80-88.

EFSA, 2005. Opinion of the scientific panel on contaminants in food chain on a request from the commission related to ergot as undersirable substance in animal feed. The EFSA Journal 225: 1-27. http://www.efsa.europa.eu/en/scdocs/doc/contam_op_ej225_ergot_en1.pdf.

Egmond, H.P., Jonker, M., 2004. Worldwide regulations for mycotoxins in food and feed in 2003. Food and Nutrition Paper No. 81. Rome (Italy): Food and Agriculture Organisation of the United Nations.

European Commission, 1992. Regulation (EEC) No. 689/92 of 19 March 1992 fixing the procedure and conditions for the taking-over of cereals by intervention agencies. Official Journal L 074: 18-22.

European Commission, 2000. Commission Regulation (EC) No 824/2000 of 19 April 2000 establishing procedures for the taking-over of cereals by intervention agencies and laying down methods of analysis for determining the quality of cereals. Official Journal L 100, 20.4.2000, p. 31-50.

European Commission, 2002a. Directive 2002/32/EC of the European parliament and of the council of 7 May 2002 on undesirable substances in animal feed. Official Journal L 140: 10-21.

European Commission, 2002b. Commission Decision 2002/657/EC of 14 August 2002, implementing Council Directive 96/25/EC concerning the performance of analytical methods and the interpretation of results. Official Journal L 221, 17.8.2002, p. 8-36.

European Commission, 2009a. Commission Regulation (EU) No 1272/2009 of 11 December 2009 laying down common detailed rules for the implementation of Council Regulation (EC) No $1234 / 2007$ as regards buying-in and selling of agricultural products under public intervention. Official Journal L 349, 29.12.2009, p. 1-68.

European Commission, 2012. Commission Regulation (EU) No 744/2012 of 16 August 2012 amending Annexes I and II to Directive 2002/32/EC of the European Parliament and of the Council as regards maximum levels for arsenic, fluorine, lead, mercury, endosulfan, dioxins, Ambrosia spp., diclazuril and lasalocid A sodium and action thresholds for dioxins. Official Journal L 219, 17.8.2012, p. 5-12.

Hoogenboom, L.A.P., 2002. The combined use of the CALUX Bioassay and the HRGC/HRMS method for the detection of novel dioxin sources and new dioxin-like compounds. Environmental Science and Pollution Research Vol.9 (5): 304-306.

IAG (International Association of Feedingstuff Analysis) - Section Feedingstuff Microscopy. 2011. Method for the determination of ergot (Claviceps purpurea Tul.) in Animal Feedingstuff. IAGMethod A4. [Internet]. January 2013. Hameln, Germany: IAG; http://www.iagmicro.org/files/iag-a4_ergot.pdf

Krska, R. \& C. Crews, 2008. Significance, chemistry and determination of ergot alkaloids: A review. Food Additives \& Contaminants: Part A, 25 (6): 722-731.

Lee, M.R., 2009a. The history of ergot of rye (Claviceps purpurea) I: From antiquity to 1900. J R Coll Physicians Edinb 39: 179-184.

Liu, X., Han, L., Veys, P., Baeten, V., Jiang, X., Dardenne, P., 2011. An overview of the legislation and light microscopy for detection of processed animal proteins in feeds. Microsc. Res. Tech. 74: 735-43. 
Lorenz, K. \& Hoseney, R.C., 1979. Ergot on cereal grains, C R C Critical Reviews in Food Science and Nutrition, 11: 311-354.

Mulder, P.P.J., L. van Raamsdonk, H. van Egmond, T. van der Horst and J. de Jong, 2012. Ergot alkaloids in animal feed. Results of a survey in The Netherlands. Report 2012.005, RIKILT, Wageningen, pp. 50 .

Raamsdonk, L.W.D. van, 2007. A survey for the presence of botanic undesirable substances in feed. Report 2007.004, RIKILT, Wageningen. P. 13 with 10 tables. Available from: http://edepot.wur.nl/39987.

Raamsdonk, L.W.D. van, C. von Holst, V. Baeten, G. Berben, Ana Boix and J. de Jong, 2007. New developments in the detection of animal proteins in feeds. Feed Science and Technology 133: 63-83.

Raamsdonk, L.W.D. van, Vancutsem, J., Jorgensen, J.S., 2009. A survey on the presence of undesirable botanical substances in feed in the European Union. Biotechnol Agron Soc Environ. 13(S): 33-38.

Scott, P.M., 2009. Ergot alkaloids: extent of human and animal exposure. World Mycotoxin Journal, 2: 141-149.

Woolf, A., 2000. Witchcraft or mycotoxin? The Salem witch trials. J Toxicol Clin Toxicol. 38: 457-60. 


\section{Annex 1 List of participants}

\begin{tabular}{|c|c|}
\hline Austrian Agency for Health and Food Safety-AGES & Austria \\
\hline CRA-W & Belgium \\
\hline FLVVT & Belgium \\
\hline Danish Veterinary and Food Administration & Denmark \\
\hline S.C.L. Laboratoire de Rennes & France \\
\hline Bayerisches Landesamt fur Gesundheit und Lebensmittelsicherheit & Germany \\
\hline CVUA-RRW & Germany \\
\hline Futtermittelinstitut Stade (LAVES) & Germany \\
\hline Landesbetrieb Hessisches Landeslabor, Landwirtschaft und Umwelt & Germany \\
\hline Landeslabor Berlin-Brandenburg & Germany \\
\hline LLFG Landesanstalt für Landwirtschaft & Germany \\
\hline LTZ Augustenberg & Germany \\
\hline LUFA Nord-West & Germany \\
\hline LUFA Rostock & Germany \\
\hline LUFA-Speyer & Germany \\
\hline SGS Germany GmbH & Germany \\
\hline $\begin{array}{l}\text { Staatliche Betriebsgesellschaft für Umwelt und Landwirtschaft, GB6-Labore } \\
\text { Landwirtschaft / LUFA, FB62 }\end{array}$ & Germany \\
\hline Thüringer Landesanstalt für Landwirtschaft & Germany \\
\hline Universität Hohenheim, LA Chemie (710) & Germany \\
\hline WESSLING GmbH & Germany \\
\hline $\begin{array}{l}\text { Department of Agriculture, Fisheries and Food, Backweston Agri } \\
\text { Laboratories }\end{array}$ & Ireland \\
\hline Inst. Zooprofilattico Sperimentale della Sardegna & Italy \\
\hline Istituto Zooprofilattico della Sicilia & Italy \\
\hline MIPAAF - ICQRF - LABORATORIO DI MODENA & Italy \\
\hline Eurofins Food Testing Rotterdam BV & Netherlands \\
\hline Nutreco Nederland BV - Masterlab & Netherlands \\
\hline Nutrilab BV & Netherlands \\
\hline TLR & Netherlands \\
\hline $\begin{array}{l}\text { University of Ljubljana, Veterinary Faculty, Natl. Veterinary Institute, Unit } \\
\text { for Pathology of Animal Nutrition and Environmental Hygiene }\end{array}$ & Slovenia \\
\hline Agroscope (ALP), Swiss Research Station & Switzerland \\
\hline
\end{tabular}




\section{Annex 2 Instructions}

\section{Instructions}

\section{Test 2015-C: ergot sclerotia in unground cereals}

The package consists of two bags with $250 \mathrm{gram}$ of unground rye. The purpose of the ring test is to detect any piece of sclerotia of Ergot as listed in Directive 2002/32/EC, consolidated version of December 2013.

For each of the two samples the number of particles and their weight in mg needs to be reported on the report sheet.

The report file will be send to you by mail. The report files consists of:

- A tab with specific instructions.

- A tab with an inquiry for a specification of the procedure.

- A tab for entering the results.

\section{All pink cells have to be filled.}

After completing the two forms "Procedure" and "Results", they have to be saved as Excel file by using "Save as ...", add your unique lab code to the end of name (replace the \# \# signs with your lab number). The forms have to be send to the organisers in two ways. Every form has to be sent by Email as Excel file and as a scan (preferably *.PDF). and send the two files to Nastasja.vanderhee@wur.nl and to Leo.vanraamsdonk@wur.nl. Results will be included in the final analyses and report only if the forms are send in by electronic mail, and after the proper receipt of the requested fee.

Closing date is Tuesday October $5^{\text {th }}, 2015$. 


\section{Annex 3 Results sample A (spike level $400 \mathrm{ppm}$ )}

\begin{tabular}{|c|c|c|c|c|c|c|c|}
\hline \multirow[t]{2}{*}{ Participant } & \multirow[t]{2}{*}{ Jar nr } & \multirow{2}{*}{$\begin{array}{l}\text { Sample size } \\
\text { gram }\end{array}$} & \multicolumn{2}{|l|}{ spiked } & \multicolumn{2}{|l|}{ recovered } & \multirow[t]{2}{*}{$+/-\%$} \\
\hline & & & $\#$ & $\mathrm{mg}$ & \# & $\mathrm{mg}$ & \\
\hline 3 & 276 & 251.2 & & 111 & 5 & 108.9 & 98.1 \\
\hline 4 & 281 & 251.0 & & 119 & 5 & 116.2 & 97.6 \\
\hline 9 & 296 & 253.1 & & 111 & 5 & 108.2 & 97.5 \\
\hline 12 & 301 & 250.9 & & 109 & 5 & 106.2 & 97.4 \\
\hline 14 & 311 & 250.0 & & 105 & 4 & 101.4 & 96.6 \\
\hline 15 & 316 & 250.9 & & 106 & 5 & 103 & 97.2 \\
\hline 20 & 321 & 256.0 & & 109 & 5 & 106 & 97.2 \\
\hline 24 & 336 & 251.6 & & 108 & 5 & 105 & 97.2 \\
\hline 28 & 346 & 251.1 & & 114 & 4 & 111.4 & 97.7 \\
\hline 32 & 356 & 252.5 & & 112 & 5 & 111 & 99.1 \\
\hline 36 & 282 & 252.9 & & 119 & 4 & 115.5 & 97.1 \\
\hline 37 & 287 & 251.5 & & 112 & 3 & 85.8 & 76.6 \\
\hline 40 & 292 & 252.7 & & 102 & 4 & 100.4 & 98.4 \\
\hline 45 & 307 & 250.0 & & 105 & 3 & 102 & 97.1 \\
\hline 48 & 317 & 250.9 & & 118 & 5 & 100 & 84.7 \\
\hline 50 & 327 & 252.0 & & 115 & 5 & 112 & 97.4 \\
\hline 52 & 332 & 248.0 & & 115 & 5 & 120 & 104.3 \\
\hline 54 & 337 & 250.0 & & 123 & 5 & 120 & 97.6 \\
\hline 5 & 286 & 250.0 & & 118 & 4 & 114 & 96.6 \\
\hline 8 & 291 & 251.0 & & 123 & 7 & 118 & 95.9 \\
\hline 22 & 326 & 250.0 & & 99 & 4 & 97.1 & 98.1 \\
\hline 29 & 351 & 251.6 & & 119 & 5 & 117 & 98.3 \\
\hline 43 & 297 & 251.2 & & 121 & 5 & 119 & 98.3 \\
\hline 23 & 331 & 250.0 & & 136 & 6 & 140 & 102.9 \\
\hline 26 & 341 & 250.0 & & 107 & 5 & 104 & 97.2 \\
\hline 34 & 277 & 252.3 & & 107 & 4 & 104.9 & 98.0 \\
\hline 44 & 302 & 251.0 & & 119 & 4 & 115 & 96.6 \\
\hline 47 & 312 & 253.2 & & 122 & 5 & 120 & 98.4 \\
\hline 49 & 322 & 250.0 & & 108 & 5 & 104.3 & 96.6 \\
\hline 13 & 306 & 251.3 & & 131 & 5 & 127.33 & 97.2 \\
\hline
\end{tabular}




\section{Annex 4 Results sample B (spike level $1000 \mathrm{ppm}$ )}

\begin{tabular}{|c|c|c|c|c|c|c|c|}
\hline \multirow[t]{2}{*}{ Participant } & \multirow[t]{2}{*}{ Jar nr } & \multirow{2}{*}{$\begin{array}{l}\text { Sample size } \\
\text { gram }\end{array}$} & \multicolumn{2}{|l|}{ spiked } & \multicolumn{2}{|l|}{ recovered } & \multirow[t]{2}{*}{$+/-\%$} \\
\hline & & & $\#$ & $\mathrm{mg}$ & $\#$ & $\mathrm{mg}$ & \\
\hline 3 & 278 & 251.5 & 11 & 271 & 11 & 266.1 & 98.2 \\
\hline 4 & 283 & 251.0 & 9 & 285 & 9 & 278.3 & 97.6 \\
\hline 9 & 298 & 255.2 & 11 & 295 & 11 & 290.7 & 98.5 \\
\hline 12 & 303 & 250.6 & 11 & 276 & 10 & 264.6 & 95.9 \\
\hline 14 & 313 & 250.0 & 8 & 283 & 8 & 276.4 & 97.7 \\
\hline 15 & 318 & 251.3 & 6 & 271 & 7 & 263 & 97.0 \\
\hline 20 & 323 & 248.0 & 11 & 285 & 10 & 265 & 93.0 \\
\hline 24 & 338 & 253.0 & 11 & 278 & 12 & 272 & 97.8 \\
\hline 28 & 348 & 252.8 & 9 & 287 & 9 & 280.1 & 97.6 \\
\hline 32 & 358 & 252.2 & 13 & 289 & 13 & 284 & 98.3 \\
\hline 36 & 284 & 250.9 & 10 & 295 & 10 & 287.7 & 97.5 \\
\hline 37 & 289 & 250.4 & 8 & 288 & 8 & 282.3 & 98.0 \\
\hline 40 & 294 & 252.9 & 13 & 297 & 13 & 292 & 98.3 \\
\hline 45 & 309 & 250.0 & 12 & 291 & 12 & 286 & 98.3 \\
\hline 48 & 319 & 254.1 & 10 & 314 & 10 & 310 & 98.7 \\
\hline 50 & 329 & 252.0 & 10 & 283 & 10 & 277 & 97.9 \\
\hline 52 & 334 & 247.0 & 7 & 308 & 7 & 290 & 94.2 \\
\hline 54 & 339 & 247.0 & 12 & 295 & 11 & 260 & 88.1 \\
\hline 5 & 288 & 250.0 & 11 & 279 & 11 & 273 & 97.8 \\
\hline 8 & 293 & 252.0 & 12 & 281 & 12 & 273 & 97.2 \\
\hline 22 & 328 & 250.0 & 11 & 296 & 11 & 292 & 98.6 \\
\hline 29 & 353 & 253.8 & 13 & 277 & 13 & 271 & 97.8 \\
\hline 43 & 299 & 252.2 & 13 & 273 & 13 & 268 & 98.2 \\
\hline 23 & 333 & 251.0 & 12 & 295 & 10 & 250 & 84.7 \\
\hline 26 & 343 & 250.0 & 9 & 283 & 8 & 262 & 92.6 \\
\hline 34 & 279 & 252.2 & 9 & 283 & 9 & 277.7 & 98.1 \\
\hline 44 & 304 & 254.0 & 10 & 273 & 11 & 300 & 109.9 \\
\hline 47 & 314 & 253.9 & 11 & 290 & 11 & 290 & 100.0 \\
\hline 49 & 324 & 250.0 & 9 & 294 & 9 & 288.8 & 98.2 \\
\hline 13 & 308 & 250.6 & 11 & 278 & 12 & 272.1 & 97.9 \\
\hline
\end{tabular}




\section{Annex 5 Overview of participants' comments}

\begin{tabular}{|c|c|}
\hline Lab nr & Comments by participant \\
\hline 3 & none \\
\hline 4 & none \\
\hline 12 & none \\
\hline 14 & all fragments counted \\
\hline 20 & none \\
\hline 24 & Both samples show nutricional traces and living beetles \\
\hline 28 & We found in both samples living corn weevil \\
\hline 32 & none \\
\hline 45 & none \\
\hline 48 & none \\
\hline 50 & none \\
\hline 52 & none \\
\hline 54 & none \\
\hline 5 & method: VDLUFA 30.2 \\
\hline 8 & method: VDLUFA MBIII 30.2 \\
\hline 22 & method: VDLUFA 30.2 \\
\hline 29 & $\begin{array}{l}\text { used method: VDLufa Bd.III } 30.2 \text { - Sample 351: } 14 \text { live Sitophilus spp. \& Sample } 353: 5 \text { live and } 2 \text { dead } \\
\text { Sitophilus spp. }\end{array}$ \\
\hline 44 & presence of wheat weevil (Sitophilus granarius) \\
\hline \multicolumn{2}{|l|}{47} \\
\hline 49 & Mijt in beide monsters aangetroffen!!! \\
\hline 13 & 1 live insect found \\
\hline
\end{tabular}


RIKILT Wageningen University \& Research P.O. Box 230

6700 AE Wageningen

The Netherlands

$\mathrm{T}+31(0) 317480256$

www.wur.eu/rikilt

RIKILT report 2016.013
The mission of Wageningen University and Research is "To explore the potential of nature to improve the quality of life". Under the banner Wageningen University \& Research, Wageningen University and the specialised research institutes of the Wageningen Research Foundation have joined forces in contributing to finding solutions to important questions in the domain of healthy food and living environment. With its roughly 30 branches, 5,000 employees and 10,000 students, Wageningen University \& Research is one of the leading organisations in its domain. The unique Wageningen approach lies in its integrated approach to issues and the collaboration between different disciplines. 



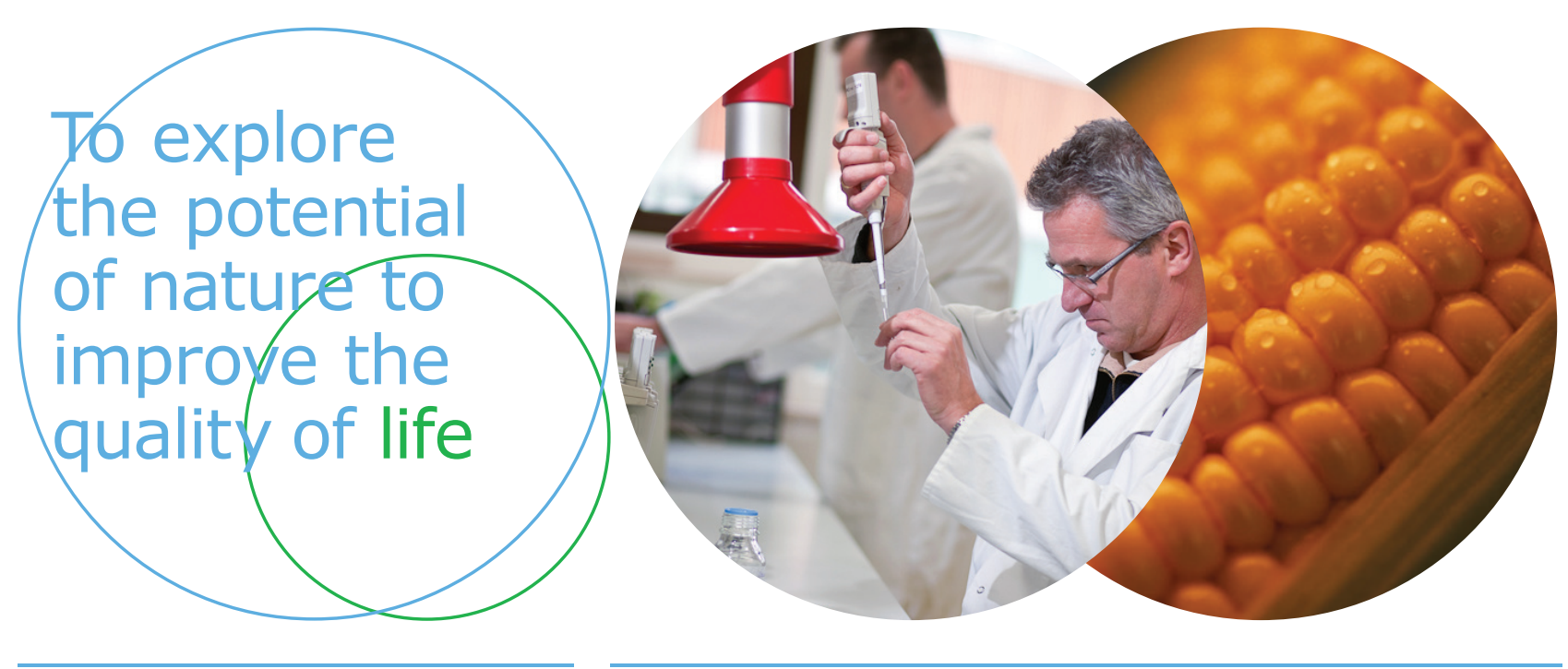

RIKILT Wageningen University \& Research P.O. Box 230

6700 AE Wageningen

The Netherlands

T +31 (0)317480256

www.wur.eu/rikilt

Report 2016.013
The mission of Wageningen University and Research is "To explore the potential of nature to improve the quality of life". Under the banner Wageningen University \& Research, Wageningen University and the specialised research institutes of the Wageningen Research Foundation have joined forces in contributing to inding solutions to important questions in the domain of healthy food and living environment. With its roughly 30 branches, 5,000 employees and 10,000 students, Wageningen University \& Research is one of the leading organisations in its domain. The unique Wageningen approach lies in its integrated approach to issues and the collaboration between different disciplines. 